\title{
Exploring youth activism on climate change: dutiful, disruptive, and dangerous dissent
}

\author{
Karen O'Brien $^{1}$, Elin Selboe ${ }^{1}$ and Bronwyn M. Hayward ${ }^{2}$
}

\begin{abstract}
The policies and decisions made today will influence climate and sustainability outcomes for the remainder of this century and beyond, and youth today have a large stake in this future. Many youth are expressing dissent toward economic, social, and environmental policies and practices that contribute to climate change in diverse ways, but clearly not all forms of climate activism have the same impact or repercussions. We have presented a typology for understanding youth dissent as expressed through climate activism. Recognizing the complex empirical reality of youth concerns about climate change, this typology has distinguished three types of activism as dutiful, disruptive, and dangerous dissent. By drawing attention to multiple ways for youth to express their political agency both within and outside of traditional political processes, we have highlighted and analyzed the diverse ways that youth are challenging power relationships and political interests to promote climate-resilient futures.
\end{abstract}

Key Words: activism; climate change; dissent; politics; sustainability; youth

\section{INTRODUCTION}

"Change the system, not the climate!" This statement can be seen on posters and banners in most climate change demonstrations. Few would argue that this is not important; research has made it clear that we need to transform systems to meet the challenges of climate change (Rockström et al. 2017, O’Brien 2018). Indeed, the implications of failing to transform toward a more sustainable future are profound (IPCC 2014). The stakes in meeting the $1.5^{\circ}$ $\mathrm{C}$ to $2^{\circ} \mathrm{C}$ targets associated with the 2015 Paris Agreement are particularly high for youth, who will have to live with and manage future risks and uncertainties associated with climate change. How can young people contribute to change within a political climate that is marked by powerful interests, strong rhetoric, and weak action on climate change?

This question conjures up an age-old political problem, where marginalized citizens and those living in distant places and times are materially and existentially threatened by the decisions and actions of other individuals, companies, or states. In the context of climate change, the challenge for democratic theorists, activists, and citizens is not just about how young people can be included in decision making. It is also a question of how they can dissent from prevailing norms, lifestyles, decisions, and actions that perpetuate business as usual and its far-reaching, long-lasting, and in some cases irreversible global impacts (Bohman 2007, Barry 2012, O'Loughlin and Gillespie 2012, Song 2012, Crayton 2014, IPCC 2014).

Widespread expressions of anger in the face of advancing climate change have resulted in some commentators describing the current period as a new "age of dissent" (Okolosie et al. 2016). We use dissent to refer to a conscious expression of disagreement with a prevailing view, policy, practice, decision, institution, or assumption that is exacerbating climate change. Some youth work directly to address climate change through small-scale and informal community-based actions, including awareness-raising events, educational programs, and sustainability campaigns (United Nations 2009, 2013). Others are active in formal and voluntary global organizations, such as 350.org, Global Power Shift, Friends of the Earth, Gen Zero, and Climate Youth (Hayward and Selboe 2014). Still others are politically engaged in more individualized and specialized ways, such as through issue-specific activism or low-threshold and part-time activities, e.g., promoting recycling or bicycling, signing petitions on social media, or consuming "green" products and following vegetarian or vegan diets (Ødegård and Berglund 2008, Ødegård 2009a, Fenton 2010, Ward 2010, Wayne et al. 2010, Manning 2013). Many young activists concerned about climate change are expressing dissent through actions that challenge business-asusual economic and social policies, including their emphasis on economic growth (Escobar 2015). This includes attempts to shift political and economic power away from the fossil fuel industries and carbon polluters through divestment campaigns, boycotts, and legal actions that emphasize environmental justice (Partridge 2008, United Nations 2013, Fisher 2016).

With youth dissent expressed through actions ranging from symbolic acts to political mobilization, clearly not all forms of climate change activism are the same (Partridge 2008, O'Loughlin and Gillespie 2012, Stitzlein 2012, Hörschelmann 2016). However, surprisingly little attention has been given to analyzing expressions of dissent among youth and their impacts on politics and power relationships. This is a concern, for as Corner et al. (2015:530) note, "Young people do not necessarily see what they can do in response to climate change, and when perceived selfefficacy is limited, personal engagement with climate change is likely to be lower." By focusing on the diversity of climate change activism, we address different ways that youth are challenging power relationships that are used as a means to constitute, legitimate, and normalize certain imaginaries and practices that perpetuate climate change (O'Brien and Selboe 2015a). Our focus is mainly on youth in high-emissions societies, though we recognize that young people all over the world are expressing their dissent against the status quo, often through climate justice movements (Escobar 2015).

${ }^{1}$ Department of Sociology and Human Geography, University of Oslo, Norway, ${ }^{2}$ Department of Political Science and International Relations, University of Canterbury, New Zealand 
Subsequently, we consider the political impacts and repercussions of different types of dissent, including how differing forms of climate activism may be perceived and met by those with strong interests in maintaining the status quo. We use status quo to refer to the "taken-for-granted" logics, institutions, and social practices that are perpetuating an inequitable and unsustainable future for youth. These include a fossil fuel-based economy that focuses on the extraction and consumption of resources to meet real or perceived needs and short-term goals, including profits for shareholders (Klein 2014). Drawing on analyses of interviews with youth conducted and informed by literature and our research on climate change activism and political participation, we present a typology of dissent among youth. This typology refers to youth activism as dutiful, disruptive, and dangerous dissent. Importantly, it is not based on the motivations or intentions of youth, but rather on the ways youth dissent(ers) could be seen from the perspective of those with political power. Recognizing that many young people engage simultaneously or sequentially with all three forms of dissent, whether as individuals or as members of organizations and social movements, we consider the ways that diverse acts of dissent can together contribute to climate-resilient futures that are both equitable and sustainable.

\section{YOUTH AND CLIMATE CHANGE}

What does climate change mean for youth today? According to the IPCC (2013), by the year 2050, a child born in 2000 is likely to experience atmospheric concentrations of $\mathrm{CO}_{2}$ of between 463 and 623 parts per million by volume (ppmv), compared with about $400 \mathrm{ppmv}$ in 2016 . They are likely to be living with $8.4-11.3$ billion others on a planet that is $0.8^{\circ} \mathrm{C}$ to $2.6^{\circ} \mathrm{C}$ warmer, with sea levels higher by $5-32 \mathrm{~cm}$ compared with 1990 (IPCC 2013). The wide range of potential futures is significant, as there is a tremendous difference between temperature increases of $0.8^{\circ} \mathrm{C}$ and $2.6^{\circ} \mathrm{C}$ in terms of impacts, risks, adaptation potential, and loss and damages. The impacts of these changes will be distributed unevenly, with the greatest risks experienced by the poor and marginalized, many of whose livelihoods are threatened by climate change. However, wealthier communities will also be affected, both directly and indirectly, through changes in ecosystem functions, extreme weather events, and the social and economic consequences of climate change (IPCC 2014). The policies and decisions made today will influence outcomes over the remainder of this century and beyond, and youth today have a large stake in this future.

In defining “youth,"we have adopted the United Nation's practice and considered the term to include people between the ages of 15 and 24 years (United Nations Department of Economic and Social Affairs [date unknown]). In everyday life, however, there are differing views on what constitutes youth, with attitudes varying within communities and across cultures about who is considered young and what roles different age groups are expected to play (Ho et al. 2015, Fisher 2016). Seen in this light, youth represents not only an age but a developmental stage characterized by expanding capacities and broadening perspectives, alongside the personal challenges associated with moving into adulthood (Arnett Jensen and Jensen Arnett 2012). Adolescence and emerging adulthood is considered a time of life characterized by openness to diverse cultural beliefs and behaviors, as well as a "relationally based social status dependent on political and historical context" (Fisher 2016:230).
Youth as a demographic category includes and conceals a diversity of beliefs, values, worldviews, and expectations about the future, as well as differing senses of agency and responsibility. Cognitive development influences the capacity of an individual to understand complex issues, and in general, youth are engaged in "an active process of increasingly organizing the relationship of the self to the environment" (Kegan 1982:113). However, many factors influence whether and how young people perceive and engage with the issue of climate change. Youth attitudes may be influenced by gender, class, social expectations, ethnicity, life course, values, and education, the same factors that influence engagement with climate change within all age groups (Leiserowitz 2006, Lorenzoni and Hulme 2009, Fisher 2016, Fløttum et al. 2016).

How messages and information about climate change are framed can influence youth perceptions and responses (Corner et al. 2015). The framing of climate change as an impending environmental disaster may contribute to a sense of despair and feelings of helplessness, which can lead to disillusion, apathy, and inactivity, or a perceived lack of potential to influence sustainability outcomes (Schreiner and Sjøberg 2005, Ødegård and Berglund 2008, Ojala 2015). However, more positive framings and emotions can invoke a sense of hope, engagement, and more constructive strategies of coping (Ojala 2012a, b, 2013). Some researchers suggest that children and youths' concern and activism about the environment is also influenced by direct exposure to climate change impacts (Strazdin and Skeat 2011). In contexts where young people have experience in securing desired change, often on unrelated issues, climate change problems may be perceived as opportunities for action and leadership (Schreiner et al. 2005, Hayward and Selboe 2014). Cultural beliefs about knowledge, for example, whether knowledge is viewed as fixed and certain or context dependent and evolving, often guide the interpretation of climate science (Fazey 2010). Next, we discuss the politics of dissent in general, before turning to youth dissent and the potential impacts of their activism on systemic change.

\section{THE POLITICS OF DISSENT}

When young citizens learn about and begin to address the issue of climate change, they inevitably have to grapple with some tough questions about how society collectively deals with complex global problems and the future. In engaging with climate change, young people are implicitly or explicitly entering into debates that involve dissenting from prevailing norms, beliefs, and practices, including economic and social norms like consumption, fossil energy use, and the unjust use of power in decision making. Such dissent is closely linked to issues of social injustice, poverty, and violence, as well as to environmental issues such as pollution and biodiversity loss.

Dissent has a long history in political thought and environmental movements throughout the world (Guha 2000, Stitzlein 2012). In his extended tract on civil disobedience, Henry David Thoreau (1849) draws on the examples of his own resistance to laws of slavery and the Mexican-American War to illustrate the concept of purposeful expression of a view at odds with the dominant opinion, even when it seems unlikely to carry the day. Thoreau argues that rather than perpetuating an injustice, citizens should follow their own conscience by doing what is right, even if this 
requires breaking the law. Thus, for Thoreau, citizens have a duty to dissent and to exercise "their own moral judgement" rather than to obey an unjust law or a government, which is often advancing the interests of a small group of powerful actors (Glick 2004:xiv). Historically, political dissent has often been associated with conscience and the responsibility to withhold consent and support, often nonviolently, but also with anger at dominant values and institutions of decision making (Malone-France 2012).

In democracies, dissent is often expressed through formal politics, particularly through opposition politics and political activism, which can be broadly described as the contestation of the exercise of unjust or illegitimate power (Stitzlein 2012, Arneil 2015). However, dissent can also be expressed informally or "off the radar" from those with power. James Scott's (1990) notion of "infrapolitics" captures the hidden, behind-the-scenes actions that do not openly confront power, yet are foundational expressions of dissent. Ann El Khoury (2015) describes how infrapolitical activism that is often covert, understated, and informal can corrode the status quo by generating options and alternatives that dilute the reach of the dominant ideology, without directly or openly challenging it. For example, the increasing number of teenagers choosing not to get driver's licenses (Sivak and Schoettle 2016) may in some cases represent an infrapolitical expression of dissent that is not directly perceived or registered as a threat to power.

\section{Dissenting youth}

We begin our analysis of youth activism by asking whether youth today are actually dissenting. The idea of dissenting youth runs counter to a common suggestion that many young citizens are indifferent to or relatively disengaged from the issue of climate change (Feldman et al. 2010, Wray-Lake et al. 2010, Liu et al. 2014). Certainly, some responses to climate change among youth can be better described as disengagement than as dissent. Young people, like adults, may avoid thinking about climate change for any number of reasons. Reasons can include fear or grief; overconfidence in the potential for technology to solve the problem; the assumption that they will be able to adapt to negative impacts; concern about an inability to effect change; frustration with existing political processes; denial of the problem; distractions and diversion of attention to more immediate social, economic, cultural, and political issues; or disinterest or disbelief in the science of climate change (Ojala 2012a, Machin 2013, Burke 2014, Fildes et al. 2014, Liu et al. 2014, Head 2016). According to Norgaard (2011), many people may also be subjects of socially organized denial, whereby information about climate change is understood in the abstract, yet disconnected from everyday political, social, and private lives.

Early studies of youth political protest about global environmental issues, peace, and civil rights often suggested that young people were predisposed to oppositional politics as a struggle to develop their identity, independent of parents or preceding generations (Erikson 1970, Iyengar 1980). More recent studies suggest that direct participation in political protest with peers has a profound, positive influence on propensity to dissent from prevailing norms (Erikson and Stoker 2011), and that the experience of participation in acts of dissent encourages greater tolerance of and respect for dissent by others (Torres 2007).
However, in either case, the ability to express political dissent rather than simply frustration requires a mature level of social consciousness, moral reasoning, and insight into the situation that an individual or community is experiencing (Schlitz et al. 2010). In this sense, expression of any form of political dissent requires support, including education, to enable young people to reflect critically. It also requires courage, particularly in situations where public opinion is highly polarized and where dissenters may be vulnerable to the scrutiny or criticism of others, or risk being attacked, repressed, or criminalized (Hayes et al. 2006, Taft and Gordon 2013, Hörschelmann 2016).

There has been long-standing contention that participation in politics and engagement with environmental issues such as climate change are the preserve or outcome of well-resourced, educated, and "postmaterialist" youth (Ingelhart 1997, Ødegård and Berglund 2008). In a North American context, Wray-Lake and Hart (2012) speculate that more educated youth, especially those with greater access to resources, are exposed to more novel and effective opportunities to engage in politics and influence policy outcomes. However, Wray-Lake and Hart (2012) add nuance to this, arguing that social inequalities compound the lack of institutional support for civic participation during childhood and adolescence. Research suggests that increasingly unequal access to education, unstable employment, and high housing costs can have a complex effect on depressing civic engagement (Flanagan and Levine 2010, Wray-Lake and Hart 2012, Honwana 2013). In an African context, some research finds that a combination of education, aspiration, and frustration at lack of opportunities for social mobility can increase the likelihood of young people engaging in protest (Resnick and Casale 2011).

Disengagement may in some cases be a response to exclusion from decision-making processes at multiple levels or an expression of frustration about political arrangements that might give voice but have little real impact and power (Ødegård 2009b, Taft and Gordon 2013). In relation to climate change, some youth may feel excluded from meaningful participation in current debates and decisions, and others may resist situations where their contributions are reduced to tokenism or "decoration" at events or forums (Hart 2008, Checkoway 2011, Taft and Gordon 2013). Such invited and managed forms of participation and citizenship do not acknowledge youth as autonomous political actors or recognize their engagement in the many alternative political arenas where they arrive at their own meanings of community, participation, and responsibility (Coleman 2010).

Nonengagement with climate change might on occasion represent an active decision to express dissent from prevailing unjust norms, policy processes, or political institutions that youth regard as illegitimate. For example, youth from ethnic minorities or lowincome communities who are experiencing diminishing prospects for effective participation in formal political processes may actively withdraw and resist engaging with national institutions that they regard with suspicion and instead seek to create alternative local forums to create a meaningful sense of belonging and agency (O'Loughlin and Gillespie 2012). However, Scoones et al. (2018) found that in many countries, state-sponsored youth organizations in rural areas aim to channel and "tame" youth aspirations in ways that suppress autonomous political mobilization. 
Describing young people as merely apathetic or indifferent to climate change can reflect a failure to take their voices seriously and to comprehend the complex situation facing new generations, including the myriad of political responses now emerging (Weller 2007). The consequence of experiencing exclusion or reduced possibility for real influence in the invited spaces of formal politics may thus encourage youth who want to make a difference to begin to critique power and express this critique through other forms of dissent (O'Loughlin and Gillespie 2012, Taft and Gordon 2013, Hörschelmann and El Refaie 2014).

It has been argued for some time that "the younger generation, in particular, may be at the forefront of those who have adapted to the newer forms of political expression, mobilization and engagement" (Norris 2003:2). New forms of dissent may include spontaneous public gatherings for discussion and expression of dissatisfaction, such as the loosely coordinated urban social movements of "indignation" in Spain, Nuit DeBout ("Night Standing") in France, or civic "occupations" in the United States (Hayward 2012). There are also forms of dissent that are less visible or obvious, expressed through subcultures of resistance over time (Stitzlein 2012). Although social media can facilitate surveillance and encourage self-censorship (Bauman and Lyon 2013), it can also be an important arena for climate change activism, contributing to information distribution, logistical support, participation fora, and "e-movements," all of which can also play a role in radical politics (Earl et al. 2010, Olsson and Dahlgren 2010, Collin 2015, Neumayer and Svensson 2016).

\section{DISSENT: DUTIFUL, DISRUPTIVE, AND DANGEROUS}

We present a typology that captures the diverse ways that youth are expressing dissent against a status quo that is contributing to dangerous climate change. The typology draws on both research and an extensive review of the literature on youth activism and political theory, based largely on Western notions of engagement and activism. This work was part of a research collaboration about youth responses to climate change carried out in Norway between 2011 and 2017 through the Voices of the Future project. This research involved literature reviews and in-depth qualitative interviews, focus groups, and discussions and feedback from young people about climate change activism (Hayward and Selboe 2014, Hayward et al. 2015, Selboe and Sæther 2018). In developing the typology, we explicitly recognize youth as political agents who may be engaging in activism in a diversity of ways. In other words, youth are neither in a state of "becoming" future citizens nor training to be participants in the sphere of formal politics; they are citizens with agency.

The typology identifies three interrelated ways of dissenting from the policies, systems, and relationships that contribute to climate change: dutiful dissent, disruptive dissent, and dangerous dissent. It is important to stress that the three types of dissent are not mutually exclusive, nor are they descriptions of how youth see or judge their own actions. Instead, they capture the different ways that youth activism engages with political power and is likely to contribute to desired changes in the status quo. We recognize that the expression of dissent is fluid and evolving, and that some youth and movements may engage with all types of dissent, either sequentially or simultaneously. Indeed, all forms of dissent play important and complementary roles in youth activism on climate change, and we do not advocate one type over another.
The three modes of dissent can be considered ideal types. For us, ideal does not mean perfect or statistically averaged; it refers to theoretically derived ideas, constructions, or mental images:

An ideal type is formed by the one-sided accentuation of
one or more point of view and by the synthesis of a great
many diffuse, discrete, more or less present and
occasionally absent concrete individual phenomena,
which are arranged according to those one-sidedly
emphasized viewpoint into a unified analytical construct.
(Weber, in Shils and Finch 1997:90)

The three ideal types presented are thus abstractions, or selections of elements that depict only certain characteristics of youth dissent and activism on climate change. Such analytical constructs are useful to simplify, synthesize, and make sense of the diversity, obscurity, and seeming chaos of the social world. Similar to the typology developed by Checkoway and Aldana (2013) to describe youth civic engagement with socially just diverse democracy, our typology recognizes that each form of dissent has its own orientation to power. Like Checkoway and Aldana (2013), we recognize the importance of new epistemologies and new forms of civic engagement to build capacity for the future. Subsequently, we begin by describing what we mean by dutiful, disruptive, and dangerous dissent, providing some examples of each and discussing their strengths and limitations.

\section{Dutiful dissent}

Dutiful dissent represents cases in which young people's concerns are voiced within existing or newly created institutional spaces. Dissent is often expressed through "joining" activities that support existing and emerging institutions and social norms to express resistance to dominant practices, such as fossil fuel production and consumerism. Through participation in established cultural practices, political institutions, and decisionmaking processes, young people may engage and interact with technical, managerial, and political elites. Dutiful dissent includes climate activism in political parties and processes, as well as in nongovernmental organizations (NGOs) that support a variety of approaches and actions for reducing greenhouse gases emissions or facilitating adaptation. These may focus on urban planning, green transport, adaptation and sustainable development projects, or national policies to support international climate agreements. Dutiful actions work through existing political and economic institutions in ways that strengthen and uphold their legitimacy, but they can also draw on existing social norms and rules to challenge unfair or unjust institutionalized practices.

Through dutiful dissent, youth activists work within existing systems to express their discontent with business as usual and to promote alternative responses to climate change. This type of dissent represents resistance to the status quo, yet it also adheres to the "script" of current institutions, hegemonic powers, and economic systems. Rather than challenge existing political decision processes, it remains dutiful to their logic and existence. For example, one young Norwegian activist acknowledged that the environmental movement in Norway has become professionalized and bureaucratic but explained that engaging with the formal political system, for instance, through writing proposals and participating in official hearings, is necessary if you want to change something (Selboe et al. 2014). 
Climate activism through membership in mainstream environmental and political organizations is the most common expression of dutiful dissent. However, young people's sense of agency, i.e., their ability to imagine and effect change, and their actions, i.e., what behaviors they engage with as citizens, may also be expressed as dissent through traditional loyalties (Bennett 2008). For example, young citizens may be encouraged to seek alternatives to prevailing ideals or practices through their religious convictions. Within this context, Pope Francis's call to address climate change could be interpreted as an appeal for dutiful dissent:

Young people demand change. They wonder how anyone can claim to be building a better future without thinking of the environmental crisis and the sufferings of the excluded. I urgently appeal, then, for a new dialogue about how we are shaping the future of our planet. We need a conversation which includes everyone, since the environmental challenge we are undergoing, and its human roots, concern and affect us all. (Francis [pope] 2015:12)

There are, however, significant risks and limitations to dutiful dissent. One risk is that climate change and other environmental issues end up as merely pollution problems to be regulated and managed, for example, through energy policies, green technologies, "smart" cities, and climate capitalism (Newell and Paterson 2010). A dutiful approach seldom disrupts the underlying causes of climate change, including the economic and development paradigms or models that are responsible for the climate change in the first place (Hayward 2012, Pelling et al. 2012, Klein 2014, Eriksen et al. 2015, O'Brien and Selboe 2015b). Furthermore, although such actions may reflect or foster an important sense of responsibility for others, deeper structural issues and political power imbalances are seldom challenged through dutiful dissent. By its very nature, dutiful dissent may promote a depoliticized or postpolitical response to climate change that frames it in consensual and technocratic terms (Swyngedouw 2010a, b, 2013, Kenis and Lievens 2014). Politics and participation, as well as citizenship education, can be promoted and directed toward consent, cohesion, and loyalty, rather than contestation and dissent (Taft and Gordon 2013, Crossouard and Dunne 2015, Hörschelmann 2016).

To be clear, dutiful dissent expressed though youth activism on climate change should not be confused with pandering to the status quo. Young people engaged in dutiful dissent are committed to change and recognize the importance and power of exploiting windows of opportunity within current structures and systems. Indeed, dutiful dissent plays an important and constructive role in ensuring that conversations about climate change are visible and that responses are prioritized and enacted through policies and practices. Dutiful actions like community gardening can also create new public spaces that provide a forum for discussions and alliances of solidarity with marginalized members of the local community, potentially encouraging collective agency and promoting progressive political activities (Crossan et al. 2016). Dutiful dissent can provide young people with important skills and insights on the current political, economic, and institutional landscape that may inspire or motivate engagement with other types of dissent, including more disruptive modes.

\section{Disruptive dissent}

Disruptive dissent can be considered a type of activism that arises when young citizens concerned about climate change question and seek to modify or change existing political and economic structures, which include norms, rules, regulations, and institutions. Disruptive actions explicitly challenge power relationships, as well as the actors and political authorities who maintain them, often through direct protests and collective organization. They may involve starting or joining petition campaigns or boycotts, disrupting international climate meetings to draw attention to hypocrisy and exclusion of important voices, or protesting key concerns through political marches or rallies. Disruptive dissent raises awareness about the underlying political, economic, and social drivers of climate change, and it draws attention to the justice and equity dimensions, acknowledging vulnerability to multiple and interacting global processes and recognizing the systemic nature of the problems and their solutions (Leichenko and O'Brien 2008, Klein 2014). Disruptive dissent is sometimes expressed through official organizations and NGOs that are considered "radical" or "alternative," but it is an essential feature of most social movements, expressed when "traditional norms no longer succeed in providing a satisfactory structure for behaviour" and when an individual finds him or herself forced to challenge the prevailing social order through various forms of nonconformity (Della Porta and Diani 2006:13).

Disruptive dissenters usually report that they are more interested in critiquing, challenging, and changing the system than working dutifully within it. Climate activists engaged with disruptive dissent are thus mobilizing against the systems and institutions they perceive as maintaining unsustainable and unjust policies and practices. This involves questioning not only the "script" of hegemonic powers and institutions, but also the actors who perpetuate them in their own interest. Through critique and action, disruptive dissent can create new spaces for alternative political voices and actors and "unveil" the underlying power dynamics and interests behind what might seem as neutral, unavoidable, or common-sense arrangements and policies (O’Brien and Selboe 2015b).

Collective action against the production and distribution of fossil fuels is a good example of disruptive dissent. This includes campaigns for universities to divest from fossil fuels, such as the Divestment Student Network (http://www.studentsdivest.org/). It is also exemplified in the "Break Free from Fossil Fuels" campaign, which describes itself as "Unwavering resistance. Fierce solidarity. Courage by the gigaton" (https://breakfree2016. org/). Although open to people of all ages, this initiative provides a platform for youth to engage in dissent that adheres to strategic values such as peaceful direct action, escalating levels of risk and pressure, mass participation, and global action. Actions include blockading and shutting down several branches of a bank in New Zealand that had \$13.5 billion invested in fossil fuels; protesting oil drilling in the Yasuni National Park in Ecuador by planting trees at the future site of an oil refinery; and dropping banners from machinery unloading coal in West Java, Indonesia, thereby bringing the coal terminal to a standstill for several hours (https:// breakfree2016.org/). 
Visible critiques and symbolic acts of dissent can trigger awareness and social reflection, generate debate, open spaces for new actors and issues, and create momentum for social change. By introducing new concepts, ideas, methods, or tactics for achieving desired change, disruptive dissent can represent an important strategy with far-reaching impacts. However, the alternative forms of citizenship and participation expressed by youth are typically resisted, rejected, or ignored by the political elite and establishment (Weller 2007, Selboe 2010, Taft and Gordon 2013). This approach also introduces risks, particularly the risk of being co-opted by prevailing agents and institutions that constrain the autonomy of youth, especially within the context of globalization and neoliberal reforms (Hayward 2012). In fact, when disruptive dissent truly threatens key economic interests or postpolitical formal politics, it may lead to silencing, exclusion, repression, or criminalization (Taft and Gordon 2013, Hörschelmann 2016). In some cases, individual rights may be curtailed through antiprotest laws or by invoking counterterrorism laws to keep people quiet.

Politicizing climate change through a critique of the status quo can open up spaces for new actors, but it may also contribute to an antagonistic and polarizing discourse that can limit mobilization and inhibit new visions and alternatives for the future (Kenis and Lievens 2014, O'Brien and Selboe 2015b). This was the case of the political movement Climate Justice Action (CJA) and its struggle to challenge the postpolitical and consensual debate on climate change. The CJA created spaces for formerly unheard voices, but the capacity and outreach of the movement intensified a we/them distinction and was limited by lack of an elaborate perspective on alternatives (Kenis and Mathijs 2014). Although disruptive dissent draws attention to power structures and represents a force operating "against power," the failure to offer viable alternatives represents a major challenge. In some cases, those who are interested in social change eventually work with those in power and express their dissent in a more dutiful manner. In other cases, disruptive dissent may provide a platform for solidarity while youth pursue change through other means, including what we refer to subsequently as dangerous dissent.

\section{Dangerous dissent}

Dangerous dissent involves a type of political activism that defies business as usual by initiating, developing, and actualizing alternatives that inspire and sustain long-term transformations. This includes a wide spectrum of actions, ideas, discourses, practices, tactics, alliances, and technologies. Dangerous dissent refers to the degree of threat that these alternatives present to established power elites and investments over the medium and long term. Like disruptive dissent, it does not recognize existing institutions and power relationships as fixed or given. What makes this type of dissent dangerous is that it generates new and alternative systems, new ways of doing things, new types of economic relationships, and new ways of organizing society. The "danger" also lies in the way that youth are claiming, taking back, or generating their own power and strengthening their personal and political agency, or simply questioning what to others appears to be inevitable, such as a fossil fuel-based economy, hyperconsumption, and increasing social inequality.
Although dangerous dissent is not always recognized as climate change activism, it can be a powerful move to undermine influential interests and transform social norms that are complicit in maintaining current systems of unsustainable growth, high greenhouse gas emissions, and deep social injustice. Dangerous dissent challenges existing paradigms or ways of understanding the relationship between climate change and social change. As Jeanes (2006:133) notes, some of the most dangerous new thinking embodies "the courage to resist the 'realization' of current creative practices in favour of the actualization of the new (previously unknown) ways of thinking."

In relation to climate change, dangerous dissent is perhaps most powerfully expressed through the postdevelopment and anticonsumerist philosophies of degrowth movements and the climate justice and just transition movements (Demaria et al. 2013, Schlosberg and Collins 2014, Escobar 2015). Degrowth movements are dangerous in that they challenge a basic tenet of capitalism, instead advocating for downscaling of production and consumption and a greater focus on care, solidarity, and cooperation. Aljets and Ebinger (2016:6) describe how some young people in Germany's degrowth movement are dissenting from unsustainable development pathways:

To us, the topic of sufficiency and the question of how everyone can have enough appears to be one of the central interfaces between the German degrowth movement and the youth environmental movement. Young environmental activists place great emphasis on personal sufficiency, and demonstrate as far as possible how sufficiency can be implemented in everyday life. They question the prevailing logic of forever-higher-faster-further-more, and derive great pleasure from energy saving, climate control, sharing, gifting, and rejecting packaging. They are pioneers of a consistently ecological and sustainable lifestyle, and demand that this be made accessible to others as well. They have recognised that the lifestyle in industrialised countries can only be achieved at the expense of the environment, nature and people in the Global South, and that their generation's environmental footprint will fall on the shoulders of the following generation.

Some actions may be dangerous without involving an open critique of the systems and structures that contribute to and perpetuate climate change. Dangerous dissent may be expressed in subversive ways that can inspire action over time, akin to what was referred to previously as infraglobalization or "subterranean" practices of everyday politics that inform and prefigure significant new social movements (Scott 1990, El Khoury 2015). In this process, new visions and powerful narratives emerge from a different view of what the system and the future might look like, and responses are no longer focused on one specific claim, e.g., reducing carbon emissions. Instead, they offer plausible alternative orientations, practices, and social arrangements for prosustainable change. It is most often expressed through propositional rather than oppositional actions, where "the aim in propositional praxis is to transmute resistance strategies towards substantive acts of creation, to make resistance secondary to the more enduring goal of building processes and structures that embody the fought-for ideals" (El Khoury 2015:109). The propositional praxis of youth activism can be particularly 
dangerous to those in power and to those with vested interests in maintaining systems that undermine sustainability.

Dangerous dissent describes actions and strategies of youth that have the potential to fundamentally change the goals, priorities, and assumptions of the "given" world. Dangerous dissent against transborder policies and environmental governance in the U.S.Mexico border region, for example, is expressed through the Sonoran Desert Narrative Network, which emerged from a meeting of the Next Generation Sonoran Desert Researchers as a means to create a new shared narrative, an alternative discourse, and the potential for grounded policy change through ecological democracy (Lejano et al. 2013, Ingram et al. 2015). Through three case studies, Lejano et al. (2013:177) reflect on how narrative networks can "enable people to present organized challenges to mainstream power relationships and conventional environmental behavior."

The seeds of dangerous dissent often germinate when young people's values and worldviews diverge from those holding power, and they flourish when young activists learn how to sustain these new values and actions, gaining not only a sense of self transcendence that can support activism in the face of repeated disappointment, the pressures of student debt, or active resistance from powerful interests, but also new solidarities with other groups that enrich and reenergize the process of effecting desired change (Hayward 2017). Indeed, socially conscious young people are increasingly seeking options that they consider to be more meaningful and that contribute to a better world, to the detriment of traditional sectors, including investment banks and established news organizations. According to a Gallup (2016) study, although millennials in the United States want a purposeful job and a life with active community and social ties, many report feeling less emotionally and behaviorally connected to their job and organization. This disengagement has repercussions for the economy. A New York Times article by Sidney Ember (2016) describes the difficulties faced by the advertising industry in recruiting young talent:

\section{A lot is at stake: If agencies cannot recruit and retain top young talent, the craft of traditional advertising - an important part of culture for better or worse-could disappear. "We have to fill the pipeline with young talent," said Tony Weisman, chief executive in North America for the agency DigitasLBi. If agencies fail to recruit and keep top young employees, he said, "We're going to become archaic."}

Dangerous dissent does not have to be strategic, but it often involves a clear vision of new and desired futures (Satell and Popovic 2017). It may emerge as part of social activism, but it goes beyond the critiques associated with disruptive dissent. For example, alternative market relationships, such as direct farmerto-consumer exchanges, can evolve to become a form of dangerous dissent. In this case, these new relationships can pose challenges to food distributors and supermarket chains. Bringing together new, seemingly unrelated actors and issues and experimenting with economic models that prioritize human relationships or with plant-based diets that respect the rights of animals while decreasing greenhouse gas emissions can be a powerful way to elicit change. Dangerous dissent thus forms the seedbed for new forms of solidarity (Bauman 2013).
However, one of the possible drawbacks to dangerous dissent is that it may pose no immediate threat to dominant systems. To some extent, dangerous dissent can be tolerated. For example, alternative communities such as transition towns may not actually challenge dominant power relations and may in fact help maintain them if the movement remains the preserve of middle-class and young elite communities (Smith 2011, Feola and Nunes 2014). In some cases, novel forms of social organization, such as the sharing economy, may not be as progressive as they seem. One criticism of the sharing economy is that venture capital and for-profit platforms have too frequently co-opted what began as a progressive, socially transformative idea (Schor 2014). Creativity and innovation have indeed become modern mantras that support capitalism (Jeanes 2006), and together with arts and literature, they may be part of what Amitav Ghosh (2016) refers to as a form of collusion with "the great derangement." Art practices that refuse to be co-opted by capitalism, such as creating noncommercial art in public spaces to share new ideas about climate change or injustice, may provide some latent examples of dangerous dissent.

Dangerous dissent is not merely about withdrawal from the system, subversion, or practices that stay "under the radar." Nor is not to be confused with the dangerous methods sometimes used to display dissent, such as violent riots of rage and extreme or fundamentalist attacks. As Barber (2003:126) argues, a "mob is not a citizenry, if an action is to be political it must ensue from forethought and deliberation, from free and conscious choice." Dangerous dissent is instead about creating alternatives that in the long run can threaten vested interests and the status quo in unconventional ways. As we discuss subsequently, a combination of dutiful, disruptive, and dangerous dissent may be necessary to support social transformations as an effective response to climate change.

\section{DISCUSSION}

The clock is ticking, and the future for young people today will be largely decided by generations that will be gone before the most severe impacts of climate change are felt. Dutiful, disruptive, and dangerous dissent represent three complementary and mutually reinforcing pathways for youth to express dissent, agency, and influence over their future. Table 1 summarizes some of the distinguishing factors among the three types, as well as the risks associated with each of them, as discussed previously. The point of this typology is not to advocate for one type of dissent over another, but rather to draw attention to the ways that the three types actively work together as expressions of dissent through climate change activism among youth. Indeed, most successful social movements, such as the civil rights, women's rights, and LGBT (lesbian, gay, bisexual, and transgender) rights movements, involved all three types of dissent, each of which contributed to reclaiming, reframing, and transforming previously stigmatized accounts of group membership.

The degrowth movement, presented previously as an example of dangerous dissent, illustrates the way that multiple types of dissent can support each other. It was launched as a challenge to continuous economic growth, with the goal of realizing a voluntary societal shrinking of production and consumption consistent with social and ecological sustainability. Demaria et al. (2013) draw attention to the diversity of ideas, strategies, and 
Table 1. Summary of three types of dissent and their distinguishing factors.

\begin{tabular}{|c|c|c|c|}
\hline $\begin{array}{l}\text { Type of Climate } \\
\text { Change Activism }\end{array}$ & $\begin{array}{l}\text { Dutiful } \\
\text { Dissent }\end{array}$ & $\begin{array}{l}\text { Disruptive } \\
\text { Dissent }\end{array}$ & $\begin{array}{l}\text { Dangerous } \\
\text { Dissent }\end{array}$ \\
\hline $\begin{array}{l}\text { Orientation to } \\
\text { prevailing power } \\
\text { relationships }\end{array}$ & $\begin{array}{l}\text { Works within existing systems and } \\
\text { power structures to effect policy } \\
\text { change }\end{array}$ & $\begin{array}{l}\text { Contests prevailing social norms and } \\
\text { policy practices to redirect policy and } \\
\text { change outcomes }\end{array}$ & $\begin{array}{l}\text { Creates and (re-)generates new and } \\
\text { alternative systems, subverting existing power } \\
\text { structures by mobilizing citizens around new } \\
\text { norms and values }\end{array}$ \\
\hline Approach & Reformist & Oppositional & Propositional \\
\hline Example of activism & $\begin{array}{l}\text { Helping university to develop an } \\
\text { ethical investment policy }\end{array}$ & $\begin{array}{l}\text { Protesting outside a local bank to get } \\
\text { them to divest from petroleum } \\
\text { industries }\end{array}$ & $\begin{array}{l}\text { Setting up an alternative local currency that } \\
\text { does not rely on existing financial institutions }\end{array}$ \\
\hline Strengths & $\begin{array}{l}\text { Provides insights into how current } \\
\text { institutions and systems function } \\
\text { Offers direct access to those holding } \\
\text { power } \\
\text { Builds legitimacy and authority } \\
\text { within existing system }\end{array}$ & $\begin{array}{l}\text { Increases awareness and engagement } \\
\text { Highlights justice and equity } \\
\text { dimensions } \\
\text { Focuses on underlying causes of } \\
\text { climate change } \\
\text { Opens spaces for new actors and voices }\end{array}$ & $\begin{array}{l}\text { Bypasses existing systems and can potentially } \\
\text { undermine them } \\
\text { Demonstrates viability of alternatives } \\
\text { Tends to be "off the radar" from those } \\
\text { threatened by alternatives }\end{array}$ \\
\hline Risks & $\begin{array}{l}\text { Co-optation; enrollment in the } \\
\text { reward system of current structures; } \\
\text { danger of normalizing the status } \\
\text { quo }\end{array}$ & $\begin{array}{l}\text { Polarization; promotion of } \\
\text { antagonisms rather than alternatives }\end{array}$ & $\begin{array}{l}\text { Creation of "parallel systems" that are } \\
\text { progressive but do not challenge status quo or } \\
\text { that risk being co-opted to reproduce business } \\
\text { as usual }\end{array}$ \\
\hline
\end{tabular}

actors involved in the degrowth movement. By identifying, naming, and valuing different socio-environmental futures and proposing radical change through alternative meanings and ways of doing things, the movement can indeed be considered a powerful example of dangerous dissent. However, elements of disruptive dissent are also visible in the movement's oppositional activism, as well as in the critique of the hegemony of economic growth. At the same time, there are also reformist strategies within the degrowth movement; dutiful dissent can be expressed by working for social transformation within existing institutions or by calling for their preservation and reform, e.g., defending democratic institutions while supporting the development of a more participatory democracy (Demaria et al. 2013). According to Demaria et al. (2013), it is precisely the innovative and coherent combination of heterogeneous concerns, demands, means, and actors within the movements that keep them dynamic and innovative. Contradictions and conflicts may create tensions within the degrowth movement, but when they are recognized and valued, they contribute to the movement's continuous evolution.

An awareness of the different modes of dissent and their strengths, limits, and implications for climate activism among youth is critical. Education plays an important role in empowering youth with the knowledge and skills to engage effectively with climate change (Westheimer and Khane 2004, Westheimer 2008). Youth education on climate change often focuses on providing information about the climate system and the impacts and consequences of climate change for society. Education for dissent and action on climate change requires critical thinking, including reflection on individual and collective attitudes and approaches to power, as well as greater attention to issues of social and environmental justice. Critical thinking is essential to challenging the assumptions and interests that maintain business as usual and for developing strategies and actions that directly confront those with vested interests in systems and structures that perpetuate climate change and social inequality (Mitchell 2007). Hytten (2016) argues that studying and participating in civic activism, social movements, collective mobilization, and resistance can provide valuable resources for deepening democracy. We suggest that through direct experiences with dutiful, disruptive, or dangerous dissent, youth may gain important insights into social change, systems change, citizenship, and democracy that many education systems are currently failing to provide (Hayward 2012).

\section{CONCLUSION}

Our goal has been to draw attention to the complex relationships of power that young activists are frequently required to navigate and to the varieties and likely consequences of diverse expressions of dissent. The typology we presented supports critical reflection on the effectiveness of diverse strategies of youth dissent, and as philosopher Hannah Arendt discussed in The Human Condition (Arendt and Canovan 1998:5), it encourages us "to think about what we are doing." If the goal is to change the system, not the climate, it may be necessary to do more than just educate young people about climate change and encourage youth activism. Instead, it may be time to recognize the many facets, forms, spaces, and expressions of youth dissent.

Despite diverse expressions, all forms of political dissent suggest a belief or presumption of agency, that is, the ability of individuals to imagine a different future and a sense of purposeful expression of opinions or actions that are at variance with dominant or commonly held beliefs. By drawing attention to multiple ways for youth to express their agency both within and outside of traditional political processes, we highlight the ways that they are challenging the interests and power relationships that are perpetuating an unsustainable future. However, not all forms of dissent and climate activism are equally challenging to the status quo, and not all forms of dissent can be interpreted in a positive light. Indeed, dissent can be manufactured as a result of failed expectations and frustration with the lack of alternatives or as a result of a lack of voice and access to democratic processes (Herman and Chomsky 2008). If there are no constructive outlets for dissent, there is a risk of moving toward withdrawal, inaction, or angry violence. Within the context of climate change, such 
anger may be directed against other marginalized people, such as migrants fleeing violent conflict, economic impoverishment, and environmental degradation.

As we have emphasized, the lines between dutiful, disruptive, and dangerous dissent are fluid rather than fixed. Rather than representing "boxes" or "categories" for classifying discrete actions, these ideal types can help us to understand and analyze the complexity of youth activism on climate change. The typology may be equally relevant to "adult" expressions of dissent. It may be particularly interesting to investigate whether the lines between "youth" and "adult" are becoming blurred as young people take greater responsibility for their future, while many adults behave as children, protecting their toys and games as the climate continues to warm. However, more empirical research is needed in different geographic and social contexts to identify how different modes of dissent are both evolving and challenging existing cultural, social, economic, and political systems, while also creating viable alternatives. There is no doubt that the visions and values of young people have to be seen, heard, prioritized, and realized through climate change activism. We argue that young people will be better placed to reclaim, reframe, and transform their future in a changing climate through critical reflection and a combination of dutiful, disruptive, and dangerous dissent.

Responses to this article can be read online at: http://www.ecologyandsociety.org/issues/responses. $\mathrm{php} / 10287$

\section{Acknowledgments:}

We would like to thank two anonymous reviewers for their valuable comments on the article, as well as the Research Council of Norway for funding Project 207582, Voices of the Future: Values and Visions of Norwegian Youth on Responses to Climate Change.

\section{LITERATURE CITED}

Aljets, J., and K. Ebinger. 2016. Youth environmental movement: implementing socio-ecological transformation with enthusiasm. Degrowth in Bewegung(en). Konzeptwek Neue Ökonomie, Leipzig, Germany. [online] URL: https://www.degrowth.de/wpcontent/uploads/2016/12/DIM_Environmental-Youth.pdf

Arendt, H., and M. Canovan. 1998. The human condition. Second edition. University of Chicago Press, Chicago, Illinois, USA. http://dx.doi.org/10.7208/chicago/9780226924571.001.0001

Arneil, B. 2015. Global citizenship vs cosmopolitanism. Pages 214-233 in T. Caraus and A. Parvu, editors. Cosmopolitanism and the legacies of dissent. Routledge, New York, New York, USA.

Arnett Jensen, L., and J. Jensen Arnett. 2012. Going global: new pathways for adolescents and emerging adults in a changing world. Journal of Social Issues 68(3):473-492. http://dx.doi. org/10.1111/j.1540-4560.2012.01759.x

Barber, B. 2003. Strong democracy: participatory politics for a new age. Twentieth Anniversary Edition. University of California Press, Berkeley, California, USA.
Barry, J. 2012. The politics of actually existing unsustainability: human flourishing in a climate-changed, carbon constrained world. Oxford University Press, Oxford, UK. http://dx.doi.org/10.1093/ acprof:oso/9780199695393.001.0001

Bauman, Z. 2013. Solidarity: a word in search of flesh. New Eastern Europe: Eurozine 2, 8 May. [online] URL: http://www. eurozine.com/articles/2013-05-08-bauman-en.html

Bauman, Z., and D. Lyon. 2013. Liquid surveillance: a conversation. Polity, Cambridge, UK.

Bennett, W. L. 2008. Civic life online: learning how digital media can engage youth. MacArthur Foundation Series on Digital Media and Learning. MIT Press, Cambridge, Massachusetts, USA.

Bohman, J. 2007. Democracy across borders: from dêmos to dêmoi. MIT Press, Cambridge, Massachusetts, USA.

Burke, L. 2014. Mission Australia Youth Survey 2014 shows kids don't care about the environment any more. News.com.au. 2 December. [online] URL: http://www.news.com.au/technology/ environment/mission-australia-youth-survey-2014-shows-kids-dontcare-about-the-environment-any-more/news-story/850913c5a5fea160c7e43164eba4b22f

Checkoway, B. 2011. What is youth participation? Children and Youth Services Review 33(2):340-345. http://dx.doi.org/10.1016/j. childyouth.2010.09.017

Checkoway, B., and A. Aldana. 2013. Four forms of youth civic engagement for diverse democracy. Children and Youth Services Review 35(11):1894-1899. http://dx.doi.org/10.1016/j.

childyouth.2013.09.005

Coleman, S. 2010. Making citizens online. From virtual boyscouts to activist networks. Pages 71-90 in T. Olsson and P. Dahlgren, editors. Young people, ICTs and democracy: theories, policies, identities, and websites. Nordicom, Göteborg, Sweden.

Collin, P. 2015. Young citizens and political participation in a digital society. Palgrave Macmillan, London, UK. http://dx.doi. org/10.1057/9781137348838

Corner, A., O. Roberts, S. Chiari, S. Völler, E. S. Mayrhuber, S. Mandl, and K. Monson. 2015. How do young people engage with climate change? The role of knowledge, values, message framing, and trusted communicators. WIREs Climate Change 6 (5):523-534. http://dx.doi.org/10.1002/wcc.353

Crayton, K. 2014. The art of racial dissent: African American political discourse in the age of Obama. Kent Law Review 89 (2):689-721.

Crossan, J., A. Cumbers, R. McMaster, and D. Shaw. 2016. Contesting neoliberal urbanism in Glasgow's community gardens: the practice of DIY citizenship. Antipode 48(4):937-955. http://dx.doi.org/10.1111/anti.12220

Crossouard, B., and M. Dunne. 2015. Politics, gender and youth citizenship in Senegal: youth policing of dissent and diversity. International Review of Education 61(1):43-60. http://dx.doi. org/10.1007/s11159-015-9466-0

Della Porta, D., and M. Diani. 2006. Social movements: an introduction. Second edition. Blackwell, Oxford, UK. 
Demaria, F., F. Schneider, F. Sekulova, and J. Martinez-Alier. 2013. What is degrowth? From an activist slogan to a social movement. Environmental Values 22(2):191-215. http://dx.doi. org/10.3197/096327113X13581561725194

Earl, J., K. Kimport, G. Prieto, C. Rush, and K. Reynoso. 2010. Changing the world one webpage at a time: conceptualizing and explaining Internet activism. Mobilization: An International Quarterly 15(4):425-446.

E1 Khoury, A. 2015. Globalization development and social justice: a propositional political approach. Routledge, Abingdon, UK.

Ember, S. 2016. Ad agencies need young talent. Cue the beanbag chairs. New York Times. 18 April. [online] URL: http://www. nytimes.com/2016/04/19/business/media/ad-agencies-need-youngtalent-cue-the-bean-bag-chairs.html

Eriksen, S., T. H. Inderberg, K. O’Brien, and L. Sygna. 2015. Introduction: development as usual is not enough. Pages 1-18 in T. H. Inderberg, S. Eriksen, K. O'Brien, and L. Sygna, editors. Climate change adaptation and development: transforming paradigms and practices. Routledge, London, UK.

Erikson, E. H. 1970. Reflections on the dissent of contemporary youth. Daedalus 99(1):154-176.

Erikson, R. S., and L. Stoker. 2011. Caught in the draft: the effects of Vietnam draft lottery status on political attitudes. American Political Science Review 105(2):221-237. http://dx.doi.org/10.1017/ $\underline{\text { S0003055411000141 }}$

Escobar, A. 2015. Degrowth, postdevelopment, and transitions: a preliminary conversation. Sustainability Science 10(3):451-462. http://dx.doi.org/10.1007/s11625-015-0297-5

Fazey, I. 2010. Resilience and higher order thinking. Ecology and Society 15(3):9. [online] URL: http://dx.doi.org/10.5751/ ES-03434-150309

Feldman, L., M. C. Nisbet, A. Leiserowitz, and E. Maibach. 2010. The climate change generation? Survey analysis of the perceptions and beliefs of young Americans. George Mason University, Center for Climate Change Communication, Fairfax, Virginia, USA.

Fenton, N. 2010. Re-imagining democracy. New media, young people, participation and politics. Pages 19-34 in T. Olsson and P. Dahlgren, editors. Young people, ICTs and democracy: theories, policies, identities, and websites. Nordicom, Göteborg, Sweden.

Feola, G., and R. Nunes. 2014. Success and failure of grassroots innovations for addressing climate change: the case of the Transition Movement. Global Environmental Change 24:232-250. http://dx.doi.org/10.1016/j.gloenvcha.2013.11.011

Fildes, J., A. Robbins, L. Cave, B. Perrens, and A. Wearring. 2014. Mission Australia's 2014 youth survey report. Mission Australia, Sydney, New South Wales, Australia.

Fisher, S. R. 2016. Life trajectories of youth committing to climate activism. Environmental Education Research 22(2):229-247. http:// dx.doi.org/10.1080/13504622.2015.1007337

Flanagan, C., and P. Levine. 2010. Civic engagement and the transition to adulthood. Future of Children 20(1):159-179. http:// dx.doi.org/10.1353/foc. 0.0043
Fløttum, K., T. Dahl, and V. Rivenes. 2016. Young Norwegians and their views on climate change and the future: findings from a climate concerned and oil-rich nation. Journal of Youth Studies 19(8):1128-1143. http://dx.doi.org/10.1080/13676261.2016.1145633

Francis (pope). 2015. Encyclical letter Laudato si' of the holy father Francis on care for our common home. Vatican Press, Vatican City. [online] URL: http://w2.vatican.va/content/dam/francesco/ pdf/encyclicals/documents/papa-francesco 20150524 enciclica-laudatosi en.pdf

Gallup. 2016. How millennials want to work and live: the six big changes leaders have to make. Gallup, Washington, D.C., USA. [online] URL: http://www.gallup.com/reports/189830/millennialswork-live.aspx

Ghosh, A. 2016. The great derangement: climate change and the unthinkable. University of Chicago Press, Chicago, Illinois, USA.

Glick, W., editor. 2004. The higher law: Thoreau on civil disobedience and reform. Princeton University Press, Princeton, New Jersey, USA.

Guha, R. 2000. Environmentalism: a global history. Oxford University Press, Oxford, UK.

Hart, R. A. 2008. Stepping back from 'the ladder': reflections on a model of participatory work with children. Pages 19-31 in A. Reid, B. B. Jensen, J. Nikel, and V. Simovska, editors. Participation and learning. Springer, Dordrecht, The Netherlands. http://dx. doi.org/10.1007/978-1-4020-6416-6_2

Hayes, A. F., D. A. Scheufele, and M. E. Huge. 2006. Nonparticipation as self-censorship: publicly observable political activity in a polarized opinion climate. Political Behavior 28 (3):259-283. http://dx.doi.org/10.1007/s11109-006-9008-3

Hayward, B. 2012. Children, citizenship and environment: nurturing a democratic imagination in a changing world. Routledge, London, UK.

Hayward, B. 2017. Sea change: climate politics and New Zealand. Bridget Williams Books, Wellington, New Zealand. http://dx.doi. org/10.7810/9781988533285

Hayward, B. M., and E. Selboe. 2014. Supporting resilient global citizenship in a changing climate: lessons from Norway, Samoa and New Zealand. Pages 79-85 in UNICEF Office of Research, editor. The challenges of climate change: children on the front line. UNICEF Office of Research, Florence, Italy.

Hayward, B., E. Selboe, and E. Plew. 2015. Citizenship for a changing global climate: learning from New Zealand and Norway. Citizenship, Social and Economics Education 14(1):19-27. http:// dx.doi.org/10.1177/2047173415577506

Head, L. 2016. Hope and grief in the Anthropocene: reconceptualising human-nature relations. Routledge, London, $\mathrm{UK}$.

Herman, E. S., and N. Chomsky. 2008. Manufacturing consent: the political economy of the mass media. The Bodley Head, London, UK.

Ho, E., A. Clarke, and I. Dougherty. 2015. Youth-led social change: topics, engagement types, organizational types, strategies, and impacts. Futures 67:52-62. http://dx.doi.org/10.1016/j. futures.2015.01.006 
Honwana, A. 2013. Youth, waithood, and protest movements in Africa. International African Institute (IAI) - Lugard Lecture 2013. African Arguments. 12 August. [online] URL: http:// africanarguments.org/2013/08/12/youth-waithood-and-protest-movementsin-africa-by-alcinda-honwanal

Hörschelmann, K. 2016. Dissent and youth citizenship. Pages 363-380 in K. Kallio, S. Mills, and T. Skelton, editors. Politics, citizenship andrights. Geographies of Children and Young People, Volume 7. Springer, Singapore. http://dx.doi.org/10.1007/978-9$\underline{81-4585-57-6 \quad 30}$

Hörschelmann , K., and E. El Refaie. 2014. Transnational citizenship, dissent and the political geographies of youth. Transactions of the Institute of British Geographers 39(3):444-456. http://dx.doi.org/10.1111/tran.12033

Hytten, K. 2016. Globalization, democracy, and social movements: the educational potential of activism. Educational Philosophy and Theory 48(10):981-996. http://dx.doi. org/10.1080/00131857.2016.1150801

Ingelhart, P. 1997. Modernization and postmodernization: cultural, economic, and political change in 43 societies. Princeton University Press, Princeton, New Jersey, USA.

Ingram, M., H. Ingram, and R. Lejano. 2015. Environmental action in the Anthropocene: the power of narrative networks. Journal of Environmental Policy \& Planning, in press http://dx.doi. org/10.1080/1523908X.2015.1113513

Intergovernmental Panel on Climate Change (IPCC). 2013. Technical summary. Pages 33-115 in T. F. Stocker, D. Qin, G.-K. Plattner, M. Tignor, S. K. Allen, J. Boschung, A. Nauels, Y. Xia, V. Bex, and P. M. Midgley, editors. Climate change 2013: the physical science basis. Contribution of Working Group I to the Fifth Assessment Report of the Intergovernmental Panel on Climate Change. Cambridge University Press, Cambridge, UK.

Intergovernmental Panel on Climate Change (IPPC). 2014. Climate change 2014 synthesis report: summary for policy makers. [online] URL: http://www.ipcc.ch/pdf/assessment-report/ar5/syr/ AR5 SYR FINAL SPM.pdf

Iyengar, S. 1980. Socialization toward democratic norms in a developing nation: approval of dissent among Indian youth. Journal of Developing Areas 14(4):553-566.

Jeanes, E. L. 2006. 'Resisting creativity, creating the new'. A Deleuzian perspective on creativity. Creativity and Innovation Management 15(2):127-134. http://dx.doi.org/10.1111/ j.1467-8691.2006.00379.x

Kegan, R. 1982. The evolving self: problem and process in human development. Harvard University Press, Cambridge, Massachusetts, USA.

Kenis, A., and M. Lievens. 2014. Searching for 'the political' in environmental politics. Environmental Politics 23(4):531-548. http://dx.doi.org/10.1080/09644016.2013.870067

Kenis, A., and E. Mathijs. 2014. Climate change and post-politics: repoliticizing the present by imagining the future? Geoforum 52:148-156. http://dx.doi.org/10.1016/j.geoforum.2014.01.009

Klein, N. 2014. This changes everything: capitalism vs. the climate. Simon and Schuster, New York, New York, USA.
Leichenko, R. M., and K. L. O'Brien. 2008. Environmental change and globalization: double exposures. Oxford University Press, Oxford, UK. http://dx.doi.org/10.1093/acprof:oso/97801951773$\underline{29.001 .0001}$

Leiserowitz, A. 2006. Climate change risk perception and policy preferences: the role of affect, imagery, and values. Climatic Change 77(1-2):45-72. http://dx.doi.org/10.1007/s10584-006-9059-9

Lejano, R., M. Ingram, and H. Ingram. 2013. The power of narrative in environmental networks. MIT Press, Cambridge, Massachusetts, USA. http://dx.doi.org/10.7551/mitpress/9780262019378.001 .0001

Liu, X., A. Vedlitz, and L. Shi. 2014. Examining the determinants of public environmental concern: evidence from national public surveys. Environmental Science \& Policy 39:77-94. http://dx.doi. org/10.1016/j.envsci.2014.02.006

Lorenzoni, I., and M. Hulme. 2009. Believing is seeing: laypeople's views of future socio-economic and climate change in England and in Italy. Public Understanding of Science 18(4):383-400. http:// dx.doi.org/10.1177/0963662508089540

Machin, A. 2013. Negotiating climate change: radical democracy and the illusion of consensus. Zed Books, London, UK.

Malone-France, D. 2012. Political dissent: a global reader. Volume 2, modern sources. Lexington Books, Lanham, Maryland, USA.

Manning, N. 2013. 'I mainly look at things on an issue by issue basis': reflexivity and phronêsis in young people's political engagements. Journal of Youth Studies 16(1):17-33. http://dx.doi. org/10.1080/13676261.2012.693586

Mitchell, T. D. 2007. Critical service-learning as social justice education: a case study of the Citizen Scholars Program. Equity \& Excellence in Education 40(2):101-112. http://dx.doi. org/10.1080/10665680701228797

Neumayer, C., and D. Svensson. 2016. Activism and radical politics in the digital age. Convergence: The Journal of Research into New Media Technologies 22(2):131-146. http://dx.doi. org/10.1177/1354856514553395

Newell, P., and M. Paterson. 2010. Climate capitalism: global warming and the transformation of the global economy. Cambridge University Press, Cambridge, UK. http://dx.doi.org/10.1017/ CBO9780511761850

Norgaard, K. M. 2011. Living in denial: climate change, denial, and everyday life. MIT Press, Cambridge, Massachusetts, USA. http://dx.doi.org/10.7551/mitpress/9780262015448.001.0001

Norris, P. 2003. Young people \& political activism: from the politics of loyalties to the politics of choice? Report for the Council of Europe Symposium: "Young people and democratic institutions: from disillusionment to participation" (Strasbourg, 27-28 November 2003). John F. Kennedy School of Government, Harvard University, Cambridge, Massachusetts, USA. [online] URL: https://www.hks.harvard.edu/fs/pnorris/Acrobat/COE.pdf

O'Brien, K. 2018. Is the $1.5^{\circ} \mathrm{C}$ target possible? Exploring the three spheres of transformation. Current Opinion in Environmental Sustainability 31:153-160. http://dx.doi.org/10.1016/j.cosust.2018.04.010 
O'Brien, K., and E. Selboe. 2015a. Climate change as an adaptive challenge. Pages 1-23 in K. O'Brien and E. Selboe, editors. The adaptive challenge of climate change. Cambridge University Press, Cambridge, Massachusetts, USA. http://dx.doi.org/10.1017/ $\underline{\text { CBO9781139149389.002 }}$

O'Brien, K., and E. Selboe. 2015b. Social transformation. The real adaptive challenge. Pages 311-324 in K. O'Brien and E. Selboe, editors. The adaptive challenge of climate change. Cambridge University Press, Cambridge, Massachusetts, USA.

Ødegård, G. 2009a. Motlos ungdom?: nytt engasjement $i$ et gammelt demokrati. Dissertation. University of Oslo, Oslo, Norway.

Ødegård, G. 2009b. Når idealismen falmer. Politisk engasjement fra ungdomstid til ungt voksenliv. Tidsskrift for Samfunnsforskning 50:131-159.

Ødegård, G., and F. Berglund. 2008. Political participation in late modernity among Norwegian youth: an individual choice of a statement of social class? Journal of Youth Studies 11(6):593-610. http://dx.doi.org/10.1080/13676260802247573

Ojala, M. 2012a. Hope and climate change: the importance of hope for environmental engagement among young people. Environmental Education Research 18(5):625-642. http://dx.doi. org/10.1080/13504622.2011.637157

Ojala, M. 2012b. Regulating worry, promoting hope: how do children, adolescents, and young adults cope with climate change? International journal of Environmentalism and Science Education 7(4):537-561.

Ojala, M. 2013. Coping with climate change among adolescents: implications for subjective well-being and environmental engagement. Sustainability 5(5):2191-2209. http://dx.doi.org/10.3390/ su5052191

Ojala, M. 2015. Hope in the face of climate change: associations with environmental engagement and student perceptions of teachers' emotion communication style and future orientation. Journal of Environmental Education 46(3):133-148. http://dx.doi. org/10.1080/00958964.2015.1021662

Okolosie, L., B. Bragg, S. Hattenstone, S. Dhaliwal, and N. Power. 2016. Why I protest - five activists on the new age of dissent. Guardian. 22 January. [online] URL: http://www.theguardian. com/commentisfree/2016/jan/22/why-i-protest-demonstrations-fiveactivists-direct-action

O’Loughlin, B., and M. Gillespie. 2012. Dissenting citizenship? Young people and political participation in the media-security nexus. Parliamentary Affairs 65(1):115-137. http://dx.doi. org/10.1093/pa/gsr055

Olsson, T., and P. Dahlgren, editors. 2010. Young people, ICTs and democracy. Nordicom, Göteborg, Sweden.

Partridge, E. 2008. From ambivalence to activism: young people's environmental views and actions. Youth Studies Australia 27 (2):18-25.

Pelling, M., D. Manuel-Navarrete, and M. Redclift. 2012. Climate change and the crisis of capitalism. Pages 1-17 in M. Pelling, D. Manuel-Navarrete, and M. Redclift, editors. Climate change and the crisis of capitalism: a chance to reclaim self, society and nature. Routledge, Abingdon, UK.

Resnick, D., and D. Casale. 2011. The political participation of Africa's youth: turnout, partisanship, and protest. World Institute for Development of Economics Research (WIDER) Working Paper 2011/056. United Nations University-WIDER, Helsinki, Finland.

Rockström, J., O. Gaffney, J. Rogelj, M. Meinshausen, N. Nakicenovic, and H. J. Schellnhuber. 2017. A roadmap for rapid decarbonization. Science 355:1269-1271. http://dx.doi.org/10.1126/ science.aah 3443

Satell, G., and S. Popovic. 2017. How protests become successful social movements. Harvard Business Review. 27 January. [online] URL: https://hbr.org/2017/01/how-protests-become-successfulsocial-movements

Schlitz, M. M., C. Vieten, and E. M. Miller. 2010. Worldview transformation and the development of social consciousness. Journal of Consciousness Studies 17(7-8):18-36.

Schlosberg, D., and L. B. Collins. 2014. From environmental to climate justice: climate change and the discourse of environmental justice. WIREs Climate Change 5:359-374. http://dx.doi. org/10.1002/wcc. 275

Schor, J. 2014. Debating the sharing economy. Great Transition Initiative, Tellus Institute, Boston, Massachusetts, USA. [online] URL: http://www.tellus.org/pub/Schor_Debating the Sharing_Economy. pdf

Schreiner, C., E. K. Henriksen, and P. J. K. Hansen. 2005. Climate education: empowering today's youth to meet tomorrow's challenges. Studies in Science Education 41(1):3-49. http://dx.doi. org/10.1080/03057260508560213

Schreiner, C., and S. Sjøberg. 2005. Empowered for action? How do young people relate to environmental challenges? Pages 53-68 in S. Alsop, editor. Beyond Cartesian dualism. Science and Technology Education Library, Volume 29. Springer, Dordrecht, The Netherlands. http://dx.doi.org/10.1007/1-4020-3808-9 5

Scoones, I., M. Edelman, S. M. Borras, Jr., R. Hall, W. Wolford, and B. White. 2018. Emancipatory rural politics: confronting authoritarian populism. Journal of Peasant Studies 45(1):1-20. http://dx.doi.org/10.1080/03066150.2017.1339693

Scott, J. C. 1990. Domination and the arts of resistance. Yale University Press, New Haven, Connecticut, USA.

Selboe, E. 2010. Youth and social change in Dakar, Senegal: intergenerational differences and power battles in local mosques. Forum for Development Studies 37(3):365-383. http://dx.doi. org/10.1080/08039410.2010.497934

Selboe, E., M. J. Nordbø, B. Hayward, and K. O’Brien. 2014 Norwegian youth mobilizing for transformation: the preconditions of resilient protest. Poster for the Resilience 2014 Conference (Montpellier, 4-8 May 2014). Resilience Alliance, Stockholm, Sweden.

Selboe, E., and E. Sæther. 2018. Økologisk medborgerskap: Norsk ungdoms syn på ansvar og løsninger I en tid med klimaendringer. Pages 183-200 in H. Harstad and G. Rusten, 
editors. Grønn omstilling: norske veivalg. Universitetsforlaget, Oslo, Norway.

Shils, E. A., and H. A. Finch, translators and editors. 1997. The methodology of the social sciences. Free, New York, New York, USA.

Sivak, M., and B. Schoettle. 2016. Recent decreases in the proportion of persons with a driver's license across all age groups. Transportation Research Institute Report, UMTRI-2016-4. University of Michigan, Ann Arbor, Michigan, USA.

Smith, A. 2011. The Transition Town Network: a review of current evolutions and renaissance. Social Movement Studies 10 (1):99-105. http://dx.doi.org/10.1080/14742837.2011.545229

Song, S. 2012. The boundary problem in democratic theory: why the demos should be bounded by the state. International Theory 4(1):39-68. http://dx.doi.org/10.1017/S1752971911000248

Stitzlein, S. M. 2012. Teaching for dissent: citizenship, education and political activism. Paradigm/Routledge, Boulder, Colorado, USA.

Strazdin, L., and H. Skeat. 2011. Weathering the future: climate change, children and young people, and decision making. Australian Research Alliance for Children and Youth, Canberra, Australian Capital Territory, Australia. [online] URL: https://www. psychology.org.au/Assets/Files/strazdins-Skeat-2011-cc-aracy-report. pdf

Swyngedouw, E. 2010a. Apocalypse forever? Theory, Culture \& Society 27(2-3):213-232. http://dx.doi.org/10.1177/0263276409358728

Swyngedouw, E. 2010b. The impossible sustainability and the post-political condition. Pages 185-205 in M. Cerreta, G. Concilio, and V. Monno, editors. Making strategies in spatial planning. Urban and Landscape Perspectives, Volume 9. Springer, Dordrecht, The Netherlands. http://dx.doi.org/10.1007/978-90-481-3106-8 11

Swyngedouw, E. 2013. The non-political politics of climate change. $A C M E$ 12(1):1-8.

Taft, J. K., and H. R. Gordon. 2013. Youth activists, youth councils, and constrained democracy. Education, Citizenship and Social Justice 8(1):87-100. http://dx.doi.org/10.1177/1746197913475765

Thoreau, H. D. 1849. On the duty of civil disobedience. Project Gutenberg eBook. Project Gutenberg Literary Archive Foundation, Salt Lake City, Utah, USA. [online] URL: http:// www.gutenberg.org/files/71/71-h/71-h.htm

Torres, M. A. 2007. Youth activists in the age of postmodern globalization: notes from an ongoing project. Children, Youth and Environments 17(2):541-562.

United Nations. 2009. Growing together in a changing climate: the United Nations, young people, and climate change. United Nations Framework Convention on Climate Change, Bonn, Germany.

United Nations. 2013. Youth in action on climate change: inspirations from around the world. United Nations Framework Convention on Climate Change Secretariat, Bonn, Germany. [online] URL: https:/www.wmo.int/youth/sites/default/files/ youth pub 2013 en m.pdf
United Nations Department of Economic and Social Affairs. [date unknown]. Definition of youth. United Nations, New York, New York, USA. [online] URL: http://www.un.org/esa/socdev/ documents/youth/fact-sheets/youth-definition.pdf

Ward, J. 2010. Purchasing or protesting? Expanding the notion of the (online) citizen consumer. Pages 35-50 in T. Olsson and P. Dahlgren, editors. Young people, ICTs and democracy: theories, policies, identities, and websites. Nordicom, Göteborg, Sweden.

Wayne, M., J. Petley, C. Murray, and L. Henderson. 2010. Television news, politics and young people: generation disconnected? Palgrave Macmillan, Basingstoke, UK. http://dx. doi.org/10.1057/9780230274754

Weller, S. 2007. Teenagers' citizenship: experiences and education. Routledge, London, UK.

Westheimer, J. 2008. No child left thinking: democracy at risk in American schools. Democratic Dialogues Series 17. University of Ottawa, Ottawa, Ontario, Canada.

Westheimer, J., and J. Khane. 2004. What kind of citizen? The politics of educating for democracy. American Educational Research Journal 41(2):237-269. http://dx.doi.org/10.3102/0002$\underline{8312041002237}$

Wray-Lake, L., C. A. Flanagan, and D. W. Osgood. 2010. Examining trends in adolescent environmental attitudes, beliefs, and behaviors across three decades. Environment and Behavior 42 (1):61-85. http://dx.doi.org/10.1177/0013916509335163

Wray-Lake, L., and D. Hart. 2012. Growing social inequalities in youth civic engagement? Evidence from the National Election Study. PS: Political Science \& Politics 45(3):456-461. http://dx. doi.org/10.1017/S1049096512000339 